\title{
Kajian kadar asam fitat dan kadar protein selama pembuatan tempe kara benguk (Mucuna pruriens) dengan variasi pengecilan ukuran dan lama fermentasi
}

\author{
Study of phytic acid and protein contents during velvet beans (Mucuna pruriens) tempe \\ production with variation of size reduction and fermentation time
}

\author{
LAELA NUR ROKHMAH, CHOIRUL ANAM, SRI HANDAJANI, DIAN RACHMAWATI \\ Jurusan Teknologi Hasil Pertanian, Fakultas Pertanian, Universitas Sebelas Maret. Jl. Ir. Sutami 36A Surakarta 57126, Jawa Tengah
}

Manuskrip diterima: 11 September 2008. Revisi disetujui: 8 Desember 2008.

\begin{abstract}
Rokhmah LN, Anam C, Handajani S, Rachmawati D. 2009. Study of phytic acid and protein contents during velvet beans (Mucuna pruriens) tempe production with variation of size reduction and fermentation time. Biofarmasi 7: 1-9. Velvet bean is one species of Leguminoceae containing phytic acid. The advantage of phytic acid is for antioxidant. Nevertheless, phytic acid has shortage, i.e. antinutritional. Phytic acid has characteristic that it can be provided from protein to form insoluble complex of phytate and protein. The formation of phytate-protein complex causes decreasing protein availability for human body so reducing the nutrition value of the food product. The aims of this research were to determine the influence of size reduction of velvet beans seed (Mucuna pruriens) and the fermentation time on the contents of phytic acid and soluble protein on the production of velvet bean (Mucuna pruriens) tempe. This research is a factorial experiment that arranged in a Randomized Complete Design (RCD) with two experimental factors including size reduction (3 kinds) and the time of fermentation ( 5 kinds). Every 12 hours fermentation time for three kinds of velvet beans seed size, the lowest phytic acid and the highest soluble protein were showed by velvet bean tempe from grinded seeds. On the fermentation time of 36 hours for three kinds of seeds size resulted in a lowest phytic acid during fermentation, i.e. $3.32 \mathrm{mg} / \mathrm{g}, 1.98 \mathrm{mg} / \mathrm{g}$, and $1.16 \mathrm{mg} / \mathrm{g}$, respectively. The contents of highest soluble protein during fermentation obtained on fermentation for 36 hours were $19.51 \mathrm{mg} / \mathrm{g}$, 23.73 $\mathrm{mg} / \mathrm{g}$, and $24.89 \mathrm{mg} / \mathrm{g}$. The fermentation time and the size of velvet bean seeds affected on phytic acid and soluble protein contents of velvet bean tempe. The longer fermentation time of velvet bean tempe caused a lower phytic acid content and a higher soluble protein content. The smaller size of velvet bean seeds on tempe caused a lower phytic acid content and a higher soluble protein content. The velvet bean tempe of grinded seeds with 36 hours fermentation had the lowest of phytic acid content and the highest of soluble protein content of all samples with the variation of reducing size and the duration of fermentation. The optimally time fermentation was recommended at 36 hours prior to solid texture, and the soluble protein and the phytic acid content on 48 fermentation were not significant.
\end{abstract}

Keywords: Fermentation time, phytic acid contents, size reduction, soluble protein contents, velvet bean

\section{PENDAHULUAN}

Salah satu sumber gizi yang dibutuhkan oleh manusia adalah protein. Protein mempunyai fungsi utama sebagai zat pembangun dan pengatur. Sebagai zat pembangun, protein merupakan bahan pembentuk jaringan-jaringan tubuh baru yang selalu berlangsung dalam tubuh. Selain itu, protein juga berfungsi sebagai bahan bakar apabila kebutuhan energi tubuh tidak terpenuhi oleh ketersediaan karbohidrat dan lemak. Terdapat dua jenis sumber protein yaitu hewani dan nabati. Meskipun pada umumnya sumber protein hewani lebih tinggi nilainya, terdapat beberapa protein nabati yang tergolong sumber protein yang tinggi nilainya, yaitu berkisar antara $16-33 \%$, misalnya pada kacang-kacangan dan biji-bijian (Soedarmo dan Sediaoetama 1973).

Protein nabati lebih banyak dikonsumsi oleh masyarakat karena harganya yang lebih terjangkau oleh masyarakat menengah ke bawah. Tempe merupakan salah satu sumber protein nabati yang sering dikonsumsi dan pada umumnya berbahan baku kedelai. Akan tetapi, akhirakhir ini harga tempe cenderung naik karena harga kedelai sebagai bahan baku naik hingga $100 \%$, yaitu mencapai Rp7.500,00 per kg (awal Januari 2008) yang sebelumnya hanya Rp3.800,00 per kg (Agustus-September 2007). Bahan baku tempe selama ini masih diimpor dari Amerika, rata-rata $40 \%$, karena produksi kedelai lokal terus mengalami penurunan $(5,2 \%)$ dan tidak dapat memenuhi kebutuhan kedelai dalam negeri yang terus meningkat (1,8\% tiap tahun) (Pitojo 2003), sedangkan tingkat impor kedelai terus meningkat.

Kenaikan harga kedelai yang berimbas pada kenaikan harga tempe mengakibatkan penurunan konsumsi tempe sebagai salah satu sumber protein oleh masyarakat. Oleh karena itu, perlu alternatif bahan baku tempe yang harganya relatif murah, sehingga kebutuhan masyarakat akan sumber protein dapat terpenuhi.

Kara benguk merupakan salah satu jenis anggota Leguminoceae yang dapat digunakan sebagai salah satu alternatif bahan baku sumber protein non kedelai yang 
dapat diolah menjadi tempe. Meskipun kadar protein kara benguk lebih rendah dari kedelai $(28,7 \%$ kara benguk dan 40,4\% kedelai), harga kara benguk lebih murah dibandingkan dengan kedelai (kara benguk Rp2.000,00 per $\mathrm{kg}$ ), sehingga tempe kara benguk dapat terjangkau oleh masyarakat. Selain itu, kara benguk diproduksi secara lokal, sehingga tidak terpengaruh oleh biaya masuk impor.

Asam fitat yang terkandung dalam kara benguk memiliki keuntungan yaitu sebagai senyawa antioksidan. Meskipun demikian, asam fitat juga memiliki kekurangan yaitu sebagai senyawa antigizi. Tingginya kadar asam fitat dalam kara benguk dapat berikatan dengan logam dan protein membentuk kompleks senyawa tidak larut, sehingga menyebabkan turunnya ketersediaan mineral dan protein bagi tubuh, dengan demikian dapat menurunkan nilai gizi produk pangan yang bersangkutan. Dalam penelitian ini akan dikaji mengenai kandungan asam fitat sebagai zat antigizi. Kandungan HCN dalam kara benguk mentah juga sangat tinggi sehingga dapat menyebabkan keracunan, bahkan kematian (dosis 0,5-3,5 mg HCN/kg berat badan) (Winarno 2002). Kerasnya biji kara benguk juga merupakan kelemahan. Akan tetapi, kekurangankekurangan tersebut dapat diatasi dengan proses yang baik dan benar, salah satunya dengan dibuat tempe, sehingga akan dihasilkan produk yang aman dan layak untuk dikonsumsi oleh masyarakat. Oleh karena itu, diperlukan suatu upaya untuk mengatasi kerasnya produk tempe kara benguk yaitu dengan melakukan pengecilan ukuran. Diduga perubahan ukuran kara benguk akan berpengaruh terhadap kadar asam fitat dan protein terlarut.

Tujuan penelitian ini adalah: 1) Mengetahui pengaruh pengecilan ukuran biji kara benguk (Mucuna pruriens) dan lama fermentasi terhadap kadar asam fitat pada pembuatan tempe kara benguk, serta 2) Mengetahui pengaruh pengecilan ukuran biji kara benguk dan lama fermentasi terhadap kadar protein pada pembuatan tempe kara benguk.

\section{BAHAN DAN METODE}

\section{Tempat dan waktu penelitian}

Penelitian dilaksanakan di Laboratorium Rekayasa Proses Pengolahan Pangan dan Hasil Pertanian, Jurusan Teknologi Hasil Pertanian, Fakultas Pertanian, Universitas Sebelas Maret Surakarta. Penelitian dilaksanakan mulai Maret-Juni 2008.

\section{Alat dan bahan}

Bahan yang digunakan yaitu kara benguk yang diperoleh dari pasar Legi Surakarta yang berasal dari Madura, air, ragi tempe merek "RAPRIMA" produksi Bandung yang diperoleh dari Koperasi "Makmur" Mojosongo, Surakarta, plastik, dan aluminium foil. Bahan kimia yang digunakan dalam penelitian ini berkualitas proanalisis, seperti $\mathrm{HNO}_{3} 0,5 \mathrm{M}, \mathrm{HNO}_{3} 0,5 \mathrm{~N}, \mathrm{FeCl}_{3}$, amil alkohol, amonium tiosianat, natrium fitat (Na-fitat), akuades, larutan Lowry A (larutan folin ciocalteau dan akuades, 1:1), Lowry $\mathrm{B}$ (campuran larutan $2 \% \mathrm{Na}_{2} \mathrm{CO}_{3}$ dalam $\mathrm{NaOH} 1 \mathrm{~N}$ dengan $\mathrm{CuSO}_{4} \cdot 5 \mathrm{H}_{2} \mathrm{O}$ dan $\mathrm{Na}$-K-tartrat $2 \%$ ), dan larutan standar BSA atau kasein.

Sementara itu, alat yang digunakan yaitu spektrofotometer (Model Shimadzu UV Mini 1240), spektrofotometer (Model Termo Electron Corporation 20D+), oven (merek Memmert UNM 400), sentrifuse, waterbath, kompor, panci, alat perajang, blender, baskom, timbangan mekanik, pengaduk, kertas saring, penggiling daging, tabung reaksi, gelas ukur, erlenmeyer, pipet ukur, pipet tetes, tabung reaksi, botol timbang, magnetic stirrer, hot plate, stopwatch, dan termometer.

\section{Rancangan penelitian}

Penelitian ini merupakan penelitian hubungan fungsional yang pendekatan variabelnya dilakukan melalui suatu eksperimen dengan memakai sampel tempe kara benguk dan rancangan dasar berupa Rancangan Acak Lengkap (RAL) pola faktorial yang terdiri dari dua faktor, yaitu variasi pengecilan ukuran (3 macam) serta variasi lama fermentasi (5 macam). Rancangan percobaan yang digunakan dapat dilihat pada Tabel 1.

\section{Pengamatan parameter/peubah}

Peubah yang digunakan dalam penelitian ini adalah sebagai berikut. Variabel bebas untuk uji kadar asam fitat di laboratorium adalah variasi lama fermentasi dan variasi pengecilan ukuran kara benguk. Variabel terikat utama adalah kadar asam fitat pada kara benguk dan tempe kara benguk. Variabel bebas untuk uji protein terlarut di laboratorium adalah variasi lama fermentasi dan variasi pengecilan ukuran kara benguk. Variabel terikat utama adalah kadar protein pada kara benguk dan tempe kara benguk.

\section{Cara kerja}

Persiapan bahan dan sortasi, Kara benguk disortasi dari cemaran fisik, kemudian ditimbang dan dicuci terlebih dahulu sebelum diproses ke tahap berikutnya.

Perendaman 1, Masing-masing sebanyak 1,5 kg kara benguk direndam selama 24 jam. Perbandingan air dan kara benguk adalah 4:1.

Perebusan, Kara benguk yang telah direndam, kemudian direbus selama 30 menit. Perbandingan air dan kara benguk adalah 4:1. Setelah dingin, kulit kara benguk dikupas.

Perendaman 2, Kara benguk yang telah dikupas kulitnya direndam kembali dalam air dengan perbandingan air dan kara benguk 4:1 selama 24 jam.

Tabel 1. Rancangan percobaan

\begin{tabular}{cccc}
\hline Lama & \multicolumn{3}{c}{ Perlakuan } \\
\cline { 2 - 4 } fermentasi & Kara utuh & Kara belah & Kara giling \\
\hline 0 jam & $\mathrm{P}_{1} \mathrm{U}$ & $\mathrm{P}_{1} \mathrm{~B}$ & $\mathrm{P}_{1} \mathrm{G}$ \\
12 jam & $\mathrm{P}_{2} \mathrm{U}$ & $\mathrm{P}_{2} \mathrm{~B}$ & $\mathrm{P}_{2} \mathrm{G}$ \\
24 jam & $\mathrm{P}_{3} \mathrm{U}$ & $\mathrm{P}_{3} \mathrm{~B}$ & $\mathrm{P}_{3} \mathrm{G}$ \\
36 jam & $\mathrm{P}_{4} \mathrm{U}$ & $\mathrm{P}_{4} \mathrm{~B}$ & $\mathrm{P}_{4} \mathrm{G}$ \\
48 jam & $\mathrm{P}_{5} \mathrm{U}$ & $\mathrm{P}_{5} \mathrm{~B}$ & $\mathrm{P}_{5} \mathrm{G}$ \\
\hline
\end{tabular}


Perendaman 3, Setelah 24 jam, diganti dengan air yang baru dan dilakukan perendaman lagi selama 24 jam dengan perbandingan air:biji kara benguk 4:1.

Perlakuan pengecilan ukuran, Kara benguk dibagi menjadi 3 (tiga) bagian yang sama banyak, 1 bagian untuk kontrol (utuh), 1 bagian dibelah (1 lembaga dibelah menjadi 3), dan 1 bagian digiling.

Pengukusan, Pengukusan dilakukan selama 25 menit dengan api sedang. Selanjutnya, biji kara benguk ditiriskan dengan menggunakan saringan dan didinginkan pada suhu kamar dan udara terbuka.

Inokulasi, Inokulasi dilakukan dengan menggunakan ragi tempe dengan perbandingan 2 gr ragi tempe dalam 1 $\mathrm{kg}$ kara benguk, selanjutnya keduanya dicampur secara homogen. Kemudian kara benguk yang telah dicampur dengan ragi tempe dimasukkan ke dalam kantong plastik yang telah dilubangi dengan ujung jarum berdiameter kecil dan berjarak $1 \times 1 \mathrm{~cm}^{2}$.

Fermentasi, Inkubasi dilakukan dengan menempatkan plastik yang sudah diisi dengan sampel, dengan ditata di atas rak pada suhu kamar selama 0, 12, 24, 36, dan 48 jam.

\section{Analisis laboratorium \\ Uji kadar asam fitat}

Pengujian ini bertujuan untuk mengetahui kadar asam fitat dalam tempe kara benguk. Pengujian kadar asam fitat dilakukan dengan menggunakan metode Davies dan Nightingale (1975). Prinsip metode ini adalah ion ferri yang membentuk kompleks dengan fitat tidak lagi dapat bereaksi dengan io-ion tiosianat untuk membentuk kompleks warna merah. Dengan adanya amil alkohol, densitas optik larutan yang diukur absorbansinya menggunakan spektrofotometer dengan panjang gelombang ( $\lambda$ ) $465 \mathrm{~nm}$ berbanding terbalik dengan konsentrasi fitat. Semakin banyak jumlah asam fitat pada bahan, absorbansinya akan semakin rendah (Davies dan Nightingale 1975).

Sebelum dianalisis, tempe dari tiap-tiap perlakuan pengecilan ukuran dioven pada suhu $100^{\circ} \mathrm{C}$ selama 2 jam. Setelah itu, bahan dihaluskan dengan menggunakan blender hingga melewati ayakan 80 mesh. Semua bahan yang telah halus disimpan dalam botol kering, ditutup rapat untuk selanjutnya dianalisis.

\section{Uji kadar protein}

Uji kadar protein dilakukan dengan menggunakan metode Lowry. Metode Lowry digunakan untuk menganalisis kadar protein terlarut dalam bahan makanan. Prinsip uji Lowry ini yaitu adanya reaksi antara $\mathrm{Cu}^{2+}$ dengan ikatan peptida dan reduksi asam fosfomolibdat dan asam fosfotungsat oleh tirosin dan triptofan (merupakan residu protein) akan menghasilkan warna biru. Kadar protein terlarut ditentukan dengan menggunakan persamaan kurva standar (Apriyantono et al. 1989).

Penentuan kadar protein pada setiap tahap pembuatan tempe kara benguk dilakukan dengan menggunakan kurva standar BSA (Bovine Serum Albumin). Hasil pembuatan kurva baku menghasilkan persamaan garis regresi $\mathrm{y}=\mathrm{a}+\mathrm{bx}$, dimana $\mathrm{y}$ adalah absorbansi dan $\mathrm{x}$ adalah kadar protein $(\mathrm{mg} / \mathrm{ml})$.

\section{Analisis data}

Pengujian statistik untuk parameter asam fitat dan protein terlarut dianalisis dengan mengaplikasikan software SPSS 11.0 menggunakan analisis variansi (ANAVA) pada $\alpha=5 \%$, kemudian dilanjutkan dengan pengujian Duncan Multiple Range Test (DMRT).

\section{HASIL DAN PEMBAHASAN}

\section{Kadar air}

Kara benguk merupakan salah satu jenis kacangkacangan yang dapat dimanfaatkan untuk diolah menjadi tempe sebagai alternatif sumber protein. Selama fermentasi tempe, mikroorganisme mencerna substrat dan menghasilkan air, karbon dioksida, dan sejumlah besar energi (ATP). Air sebagai salah satu hasil metabolisme, sangat berpengaruh terhadap komponen-komponen lain, termasuk pertumbuhan kapang sebagai mikroorganisme yang berperan dalam fermentasi tempe. Dalam penelitian ini, dengan variabel variasi lama fermentasi dan variasi pengecilan ukuran, air yang dihasilkan dihitung sebagai kadar air dalam bahan yang dapat dilihat pada Gambar 1 dan Tabel 2. Kadar air digunakan untuk menghitung kadar asam fitat dan kadar protein terlarut dalam berat kering.

Berdasarkan data pada Tabel 2, kadar air tempe kara benguk dengan berbagai variasi lama fermentasi dan variasi pengecilan ukuran berkisar antara 6,94-27,48\%. Pada fermentasi selama 0 jam pada tempe kara benguk dengan perlakuan belah $(8,41 \%)$ dan giling $(7,44 \%)$, masing-masing menunjukkan perbedaan yang nyata apabila dibandingkan dengan kara benguk biji utuh $(27,48 \%)$, sedangkan antara tempe kara benguk biji belah dan giling tidak menunjukkan perbedaan yang nyata. Hal ini karena proses pengukusan yang dilakukan sebelum fermentasi. Proses pengukusan mengakibatkan penurunan kadar air karena panas yang dihasilkan akan menguapkan sebagian air dalam bahan. Kadar air tempe kara benguk dengan biji yang berukuran lebih kecil akan lebih rendah apabila dibandingkan pada tempe kara benguk dengan ukuran biji yang lebih besar. Dalam hal ini, kadar air pada tempe kara benguk biji utuh paling besar dibandingkan kara benguk biji belah dan giling, sedangkan pada kara benguk biji belah lebih besar dibandingkan biji giling. Selama proses pengukusan, panas yang dihasilkan dari proses pengukusan akan menguapkan air dalam bahan, sehingga semakin besar ukuran biji kara benguk maka air yang teruapkan semakin sedikit, karena uap panas sulit menembus biji karena luas permukaannya yang kecil. Sebaliknya, semakin kecil ukuran biji kara benguk maka kandungan air dalam biji kara yang teruapkan semakin banyak karena uap panas semakin mudah menguapkan air dalam biji kara. Perbedaan kadar air yang tidak berbeda nyata pada tempe kara benguk biji belah dan giling dikarenakan biji kara benguk yang digiling berukuran kecil, sehingga rongga antar biji kara benguk giling sempit dan menyebabkan uap air sulit teruapkan akibat air yang terperangkap.

Fermentasi selama 12 jam memberikan hasil kadar air yang berbeda nyata pada tempe kara benguk biji utuh, belah, dan giling. Air merupakan salah satu produk hasil 
fermentasi aerob. Pada fermentasi selama 12 jam, ragi yang digunakan dalam fermentasi tempe sudah melakukan proses metabolisme dan merombak senyawa makromolekul pada biji kara benguk menjadi senyawa yang lebih sederhana meskipun belum sempurna. Hal itu ditunjukkan dengan kenaikan kadar air pada tempe kara benguk biji belah dan giling (dari $8,41 \%$ menjadi $15,87 \%$ pada kara benguk biji belah dan dari 7,44\% menjadi $11,23 \%$ pada kara benguk biji giling), namun pada tempe kara benguk utuh mengalami penurunan (dari 27,48\% menjadi 21,00\%). Sebenarnya pada tempe kara benguk biji utuh juga dihasilkan air sebagai hasil metabolism, namun jumlahnya tidak sebanyak yang dihasilkan oleh tempe kara benguk biji belah dan giling. Hal ini dikarenakan ukuran biji pada tempe kara benguk utuh besar, sehingga metabolisme ragi tidak sebesar pada tempe kara benguk belah dan giling. Penurunan kadar air tersebut disebabkan sebagian air menguap akibat panas yang dihasilkan selama fermentasi, dan akibat kontak dengan udara meskipun sebagian air digunakan untuk pertumbuhan ragi. Hal ini sesuai dengan Rosningsih (2000) yang menyatakan bahwa kapang membutuhkan air untuk proses metabolisme.

Fermentasi selama 24 jam memberikan hasil yang berbeda nyata antara tempe kara benguk biji belah dan giling $(10,97 \%$ dan $10,06 \%)$ dibandingkan dengan kara benguk utuh $(8,77 \%)$, sedangkan antara tempe kara benguk biji belah dan giling memberikan hasil yang tidak berbeda nyata. Fermentasi selama 24 jam untuk tempe kara benguk biji utuh dan belah menunjukkan penurunan kadar air yang berbeda dengan fermentasi selama 12 jam. Penurunan kadar air pada kara benguk biji utuh terjadi secara drastis yaitu dari $21,00 \%$ menjadi $8,77 \%$, sedangkan pada tempe kara benguk belah dari $15,87 \%$ menjadi $10,97 \%$, tidak sedrastis pada tempe kara benguk utuh. Hal ini diduga pada fermentasi selama 24 jam, aktivitas ragi mengalami penurunan, sehingga kadar air yang dihasilkan juga mengalami penurunan.

Kadar air pada fermentasi selama 36 jam untuk biji belah dan giling mengalami penurunan dibanding fermentasi selama 24 jam yang berbeda nyata, berturutturut untuk kara benguk biji belah dan giling menjadi $6,94 \%$ dan 7,62\%. Pada fermentasi selama 36 jam ini, aktivitas kapang semakin mengalami penurunan. Penurunan aktivitas mikrobia secara eksponensial ini merupakan penurunan aktivitas yang terjadi secara garis lurus. Oleh karena aktivitas mikrobia menurun maka hasil metabolisme juga mengalami penurunan, termasuk air. Akan tetapi, terjadi kenaikan kadar air yang tidak berbeda nyata pada tempe kara benguk utuh, belah, dan giling pada fermentasi selama 48 jam. Kenaikan kadar air pada akhir fermentasi ini terjadi akibat peningkatan kembali aktivitas ragi yang merupakan penyimpangan yang dialami oleh jamur benang. Hal ini sesuai dengan pendapat Wibowo (1990) yang menyatakan bahwa pertumbuhan jamur benang mudah mengalami penyimpangan dari hukum pertumbuhan logaritmik karena suplai oksigen menjadi pembatas pertumbuhan. Selain itu, kondisi tersebut terutama disebabkan oleh terjadinya perubahan lingkungan yang akan menyebabkan terjadinya perubahan konstituen biomassa.

\section{Kadar asam fitat}

Kara benguk merupakan salah satu anggota Leguminoceae sebagai sumber protein, namun mengandung asam fitat. Asam fitat, suatu heksafosfor dari mioinositol, adalah asam kuat yang membentuk garam tidak larut dengan beberapa mineral dan protein. Asam fitat dapat dikurangi salah satunya dengan diolah menjadi tempe. Pada fermentasi tempe kara benguk digunakan ragi yang melibatkan berbagai jenis mikrobia yang dapat menghasilkan enzim fitase, sehingga pemecahan fitat berlangsung sangat cepat. Keberadaan mikroorganisme pada ragi mempunyai peranan penting, khususnya dalam membantu menurunkan asam fitat. Ragi tempe yang umumnya terbuat dari kapang Rhizopus menghasilkan enzim fitase yang merupakan salah satu enzim yang dapat menghidrolisis asam fitat menjadi inositol dan orthofosfat. Kadar asam fitat pada sampel dengan variasi lama fermentasi dan pengecilan ukuran dapat dilihat pada Tabel 2.

Biji kara benguk yang telah direndam, direbus, dan dikukus, diinokulasikan dengan ragi tempe, dibungkus dengan plastik yang dilubangi dengan jarum, dan diinkubasi pada suhu kamar $\left(37^{\circ} \mathrm{C}\right)$ selama $0,12,24,36$, dan 48 jam. Pada fermentasi selama 0 jam, kadar asam fitat pada tempe kara benguk biji utuh tidak berbeda nyata dengan tempe kara benguk biji belah (masing-masing 5,11 $\mathrm{mg} / \mathrm{g}$ dan $4,66 \mathrm{mg} / \mathrm{g}$ ), namun berbeda nyata dengan tempe kara benguk biji giling $(4,04 \mathrm{mg} / \mathrm{g})$. Akan tetapi, tempe kara biji belah tidak berbeda nyata dengan tempe kara benguk biji giling. Perbedaan kadar asam fitat pada ketiga jenis biji kara benguk pada fermentasi selama 0 jam dikarenakan proses pengukusan. Proses pengukusan dilakukan sebelum proses fermentasi. Panas yang dihasilkan selama proses pengukusan dapat menurunkan kadar asam fitat meskipun cara ini bukan merupakan cara yang efektif untuk mereduksi asam fitat, hal ini sesuai dengan pendapat Muchtadi dan Sugiyono (1992) yang menyebutkan bahwa asam fitat sangat tahan terhadap pemanasan selama pengolahan. Hal ini terbukti dari kadar asam fitat yang diperoleh selama penelitian. Dengan perbedaan ukuran biji kara dihasilkan kadar asam fitat yang tidak berbeda nyata antara tempe kara benguk biji utuh dengan biji belah, namun berbeda nyata dengan tempe kara benguk biji giling, sedangkan tempe kara benguk biji belah tidak berbeda nyata dengan tempe kara benguk biji giling. Penetrasi panas pada tempe kara benguk biji giling lebih besar dibandingkan biji belah dan utuh. Semakin kecil ukuran biji maka penetrasi panas semakin mudah.

Pada fermentasi selama 12 jam, ragi sudah melakukan aktivitas metabolisme dan enzim fitase yang dihasilkan sudah mulai menghidrolisis asam fitat. Kadar asam fitat pada tempe kara benguk biji utuh dan belah berbeda nyata dengan tempe kara benguk biji giling $(3,74 \mathrm{mg} / \mathrm{g})$, sedangkan antara tempe kara benguk biji utuh dan biji belah tidak berbeda nyata $(5,06 \mathrm{mg} / \mathrm{g}$ dan $4,57 \mathrm{mg} / \mathrm{g})$. Hal ini menunjukkan enzim fitase mudah menghidrolisis asam fitat pada biji kara benguk yang berukuran lebih kecil karena hifa kapang lebih mudah menembus biji kara benguk yang berukuran lebih kecil. Hasil tersebut sesuai dengan pernyataan Apriadji (2008) bahwa pada pembuatan 
tempe kedelai pecah bahwa tempe yang butiran bijinya pecah-pecah, kapang akan lebih mudah menembus kedelai. Kapang terdiri dari benang yang disebut hifa, kumpulan hifa ini dikenal sebagai miselium. Kapang tumbuh dengan cara memperpanjang hifa (Buckle 1985). Semakin kecil ukuran butiran biji tempe kara benguk maka semakin mudah kapang menembus biji kara benguk dan semakin banyak asam fitat yang diuraikan oleh enzim fitase yang dihasilkan oleh kapang.

Semakin lama waktu fermentasi, miselium jamur semakin tebal akibat pertumbuhan ragi yang semakin meningkat. Dengan pertumbuhan ragi dan semakin tebalnya miselium jamur maka enzim fitase yang diproduksi semakin meningkat dengan ditunjukkan semakin menurunnya kadar asam fitat. Pada fermentasi selama 24 jam, miselium jamur semakin tebal dibandingkan dengan fermentasi sebelumnya. Kadar asam fitat pada tempe kara benguk biji utuh berbeda nyata dengan biji belah dan giling pada waktu fermentasi yang sama. Hal ini menunjukkan bahwa pertumbuhan jamur pada tempe kara benguk biji belah dan giling relatif cepat dan seimbang apabila dibandingkan dengan tempe kara benguk biji utuh karena hifa jamur lebih mudah menembus biji kara benguk yang ukurannya semakin kecil.

Kadar asam fitat pada fermentasi selama 36 jam mengalami penurunan yang berbeda nyata antar perlakuan dengan fermentasi sebelumnya. Hal ini diduga pada fermentasi selama 36 jam merupakan fase puncak pertumbuhan ragi tempe. Pada fase tersebut, kapang yang telah beradaptasi terhadap kondisi baru akan tumbuh secara eksponensial sampai jumlah maksimum yang dapat didukung oleh kondisi lingkungan yang dicapai (Buckle et al. 1985). Dengan meningkatnya pertumbuhan ragi maka enzim fitase yang dihasilkan juga mengalami peningkatan, sehingga asam fitat yang terhidrolisis semakin banyak. Kadar asam fitat pada tempe kara benguk biji utuh, belah, dan giling berturut-turut $3,32 \mathrm{mg} / \mathrm{g}, 1,98 \mathrm{mg} / \mathrm{g}$, dan 1,16 $\mathrm{mg} / \mathrm{g}$. Penurunan kadar asam fitat yang signifikan ini selain disebabkan oleh kapang ragi tempe, juga dapat disebabkan oleh aktivitas bakteri yang tumbuh dengan baik. Sudarmadji (1975) mengamati pertumbuhan Bacillus licheniformis dan Bacillus cereus pada tempe setelah fermentasi selama 24 jam sampai 36 jam. Pangastuti dan Triwibowo (1996) melaporkan adanya aktivitas fitase pada bakteri Bacillus subtilis. Dengan demikian, turunnya kadar asam fitat selama fermentasi tidak hanya disebabkan oleh adanya jamur, tetapi diduga juga disebabkan oleh pertumbuhan bakteri selama pembuatan tempe.

Fermentasi selama 48 jam merupakan akhir fermentasi pada penelitian ini. Kadar asam fitat pada tempe kara benguk biji belah dan giling tidak berbeda nyata, sedangkan tempe kara benguk biji utuh dengan biji belah dan giling berbeda nyata, berturut-turut 3,08 mg/g, 1,44 $\mathrm{mg} / \mathrm{g}$, dan $1,05 \mathrm{mg} / \mathrm{g}$ untuk tempe kara benguk biji utuh, belah, dan giling. Kadar asam fitat pada fermentasi selama 48 jam tidak berbeda nyata dengan fermentasi selama 36 jam untuk semua variasi pengecilan ukuran. Pada fermentasi tersebut diduga merupakan fase stasioner menuju tahap kematian karena penurunan kadar asam fitat tidak berbeda nyata dengan fermentasi selama 36 jam, namun kadarnya mengalami penurunan.

Sejalan dengan lamanya fermentasi, semakin lama fermentasi maka kadar asam fitat semakin menurun. Untuk tempe kara benguk biji utuh, pada awal fermentasi kadar asam fitat sebesar $5,11 \mathrm{mg} / \mathrm{g}$ dan mengalami penurunan pada akhir fermentasi menjadi $3,08 \mathrm{mg} / \mathrm{g}$. Penurunan terjadi dari $71,87 \%$ menjadi $43,32 \%$ apabila dibandingkan dengan kadar asam fitat pada bahan mentah. Penurunan tersebut berbeda nyata pada kadar awal fermentasi dan akhir fermentasi. Kadar asam fitat tempe kara benguk biji belah pada awal fermentasi dari 4,66 mg/g menjadi 1,44 $\mathrm{mg} / \mathrm{g}$ pada akhir fermentasi. Penurunan terjadi dari $65,54 \%$ menjadi hanya sekitar 20,25\%. Tempe kara benguk biji giling pada awal fermentasi memiliki kadar asam fitat dari $4,04 \mathrm{mg} / \mathrm{g}$ menjadi $1,05 \mathrm{mg} / \mathrm{g}$ pada akhir fermentasi. Kadar asam fitat pada semua ukuran biji kara benguk berbeda nyata pada awal fermentasi dengan akhir fermentasi. Hal ini berarti lama fermentasi berpengaruh dalam menurunkan kadar asam fitat tempe kara benguk.

Di antara 4 (empat) waktu fermentasi, kadar asam fitat terendah diperoleh pada fermentasi selama 36 jam, baik tempe kara benguk biji utuh $(3,32 \mathrm{mg} / \mathrm{g})$, kara benguk biji belah $(1,98 \mathrm{mg} / \mathrm{g})$, dan kara benguk biji giling $(1,16 \mathrm{mg} / \mathrm{g})$. Meskipun kadar asam fitat pada fermentasi selama 48 jam lebih rendah, nilainya tidak berbeda nyata dengan fermentasi selama 36 jam, sehingga apabila dilihat dari aspek kadar asam fitat, pada fermentasi selama 36 jam fermentasi dapat dihentikan karena kadarnya sudah rendah.

Berdasarkan Gambar 2 dapat dilihat bahwa variasi ukuran biji berpengaruh terhadap kadar asam fitat selama fermentasi dengan perlakuan penggilingin memiliki kadar asam fitat paling rendah diantara dua perlakuan lainnya. Hal ini diduga karena aktivitas fermentasi dilakukan oleh Rhizopus oligosporus, meskipun tidak murni, karena yang dalam penelitian ini digunakan ragi. Menurut Sutardi (1988), Rhizopus oligosporus merupakan salah satu jenis jamur yang dapat menghasilkan fitase yang dapat menghidrolisis asam fitat. Jenis jamur lain yang dapat menghasilkan fitase adalah Aspergillus oryzae NRRL 1988, Rhizopus oligosporus NRRL 3671, dan Neurospora sitophilla ATCC 14151 (Tranggono dan Hastuti 1993). Sebenarnya dalam kacang-kacangan dan serealia terdapat enzim fitase dalam jumlah yang sangat sedikit dan dalam kondisi terinhibisi oleh substrat (asam fitat) (Widowati 2008), sehingga diperlukan enzim fitase secara ekstraseluler yang dapat dilakukan melalui proses fermentasi.

Biji kara benguk yang digiling lebih mudah ditembus oleh miselium jamur yang menghubungkan antara biji-biji tersebut. Hal ini terlihat dari tekstur tempe kara benguk yang digiling lebih kompak. Semakin mudah biji kara benguk ditembus oleh miselium jamur maka akan semakin tinggi aktivitas enzim fitase untuk menghidrolisis asam fitat yang terdapat dalam endosperm biji kara benguk. Sebaliknya, kara benguk utuh akan sulit ditembus bijinya oleh miselium jamur, sehingga asam fitat yang terhidrolisis oleh fitase tidak sebanyak pada kara benguk giling. Pada penelitian pendahuluan diketahui bahwa asam fitat pada kara benguk sebagian besar terkandung di dalam 
endosperm, karena penurunan kadar asam fitat secara signifikan terjadi ketika proses fermentasi dibandingkan proses pengupasan kulit yang diikuti dengan perendaman, yaitu dari $6,78 \mathrm{mg} / \mathrm{g}$ menjadi $5,66 \mathrm{mg} / \mathrm{g}$. Hasil ini diperkuat dengan pendapat Arinanti (2005) bahwa asam fitat pada dry bean utuh dan dikupas mempunyai asam fitat yang berbeda. Jumlah asam fitat pada biji dry bean yang dikupas (dari berbagai varietas) meningkat 7-60\% dibanding bentuk utuhnya. Hal ini berarti untuk produk kacang-kacangan, sebagian besar asam fitat terdapat pada bagian kotiledon, sedangkan pada produk serealia, asam fitat terbanyak terdapat pada aleuron (Reddy 1982; Arinanti 2005). Kadar asam fitat pada akhir fermentasi tempe kara benguk utuh paling tinggi apabila dibandingkan dengan kedua perlakuan lainnya yaitu sebesar $3,08 \mathrm{mg} / \mathrm{g}$, apabila dibandingkan dengan kadar asam fitat pada biji kara benguk mentah,

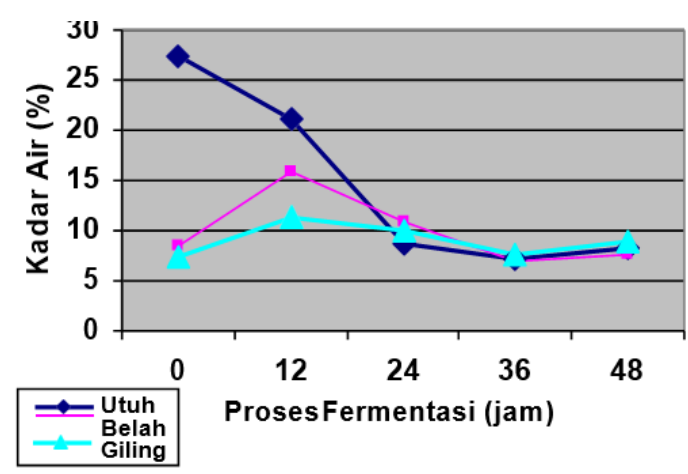

Gambar 1. Kadar air pada tempe kara benguk selama fermentasi

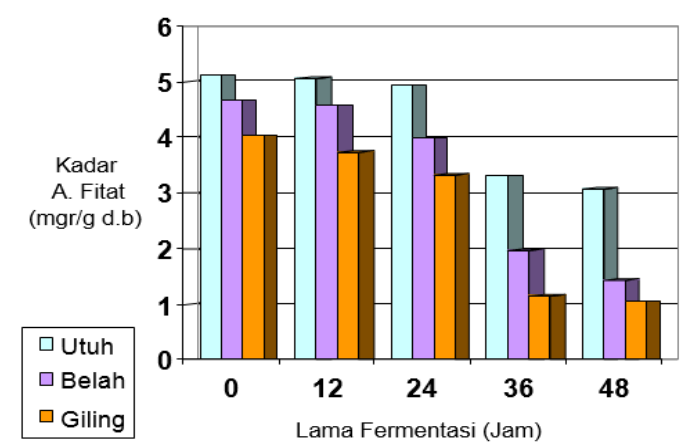

Gambar 2. Kadar asam fitat pada tempe kara benguk selama fermentasi asam fitat tinggal $43,22 \%$. Kadar asam fitat pada tempe kara benguk biji belah pada akhir fermentasi sebesar 1,44 $\mathrm{mg} / \mathrm{g}$, apabila dibandingkan dengan kadar asam fitat kara mentah, asam fitat tinggal $20,25 \%$. Kadar asam fitat pada tempe kara benguk biji giling pada akhir fermentasi sebesar $1,05 \mathrm{mg} / \mathrm{g}$, apabila dibandingkan dengan kadar asam fitat kara mentah, kadar asam fitat tinggal 14,77\%.

Pada penelitian sebelumnya yang dilakukan oleh Tranggono dan Hastuti (1993), pembuatan tempe kara benguk biji utuh dengan variasi lama fermentasi 0, 12, 24, 36 , dan 48 jam, kadar asam fitat dalam tempe kara benguk utuh sebesar 47,00\%. Hasil ini tidak jauh berbeda dengan hasil penelitian ini yaitu sebesar $43,32 \%$. Hal ini diduga karena perbedaan varietas kara benguk sebagai bahan baku pembuatan tempe dan alat yang digunakan berpengaruh terhadap perbedaan hasil yang diperoleh.

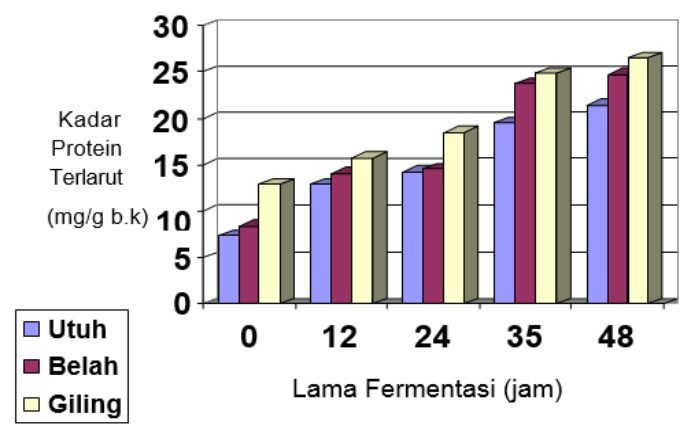

Gambar 3. Kadar protein terlarut pada tempe kara benguk selama fermentasi

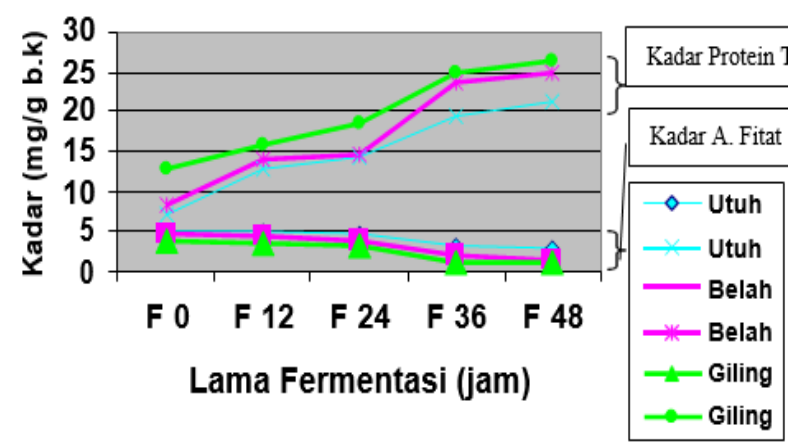

Gambar 4. Hubungan asam fitat dan kadar protein pada tempe kara benguk selama fermentasi

Tabel 2. Kadar air, asam fitat dan protein pada tempe kara benguk dengan perlakuan lama fermentasi dan pengecilan ukuran biji

\begin{tabular}{|c|c|c|c|c|c|c|c|c|c|}
\hline \multirow{2}{*}{$\begin{array}{c}\text { Proses } \\
\text { fermentasi }\end{array}$} & \multicolumn{3}{|c|}{ Kadar air (\%) } & \multicolumn{3}{|c|}{ Kadar asam fitat (mg/g) } & \multicolumn{3}{|c|}{ Kadar protein (mg/g) } \\
\hline & Biji utuh & Biji belah & Biji giling & Biji utuh & Biji belah & Biji giling & Biji utuh & Biji belah & Biji giling \\
\hline 0 jam & $27,48^{\mathrm{a}}$ & $8,41^{\mathrm{e}, \mathrm{f}, \mathrm{g}}$ & $7,44^{f, g}$ & $5,11^{\mathrm{a}}$ & $4,66^{\mathrm{a}, \mathrm{b}}$ & $4,04^{\mathrm{b}, \mathrm{c}, \mathrm{d}}$ & $7,32^{\mathrm{g}}$ & $8,39^{\mathrm{g}}$ & $12,92^{\mathrm{f}}$ \\
\hline $12 \mathrm{jam}$ & $21,00^{\mathrm{b}}$ & $15,87^{\mathrm{c}}$ & $11,23^{\mathrm{d}}$ & $5,06^{\mathrm{a}}$ & $4,57^{\mathrm{a}, \mathrm{b}, \mathrm{c}}$ & $3,74^{\mathrm{d}, \mathrm{e}, \mathrm{f}}$ & $12,85^{\mathrm{f}}$ & $14,10^{\mathrm{e}, \mathrm{f}}$ & $15,76^{\mathrm{e}}$ \\
\hline $24 \mathrm{jam}$ & $8,77^{\mathrm{e}, \mathrm{f}}$ & $10,97^{\mathrm{d}}$ & $10,06^{\mathrm{d}, \mathrm{e}}$ & $4,93^{\mathrm{a}}$ & $3,97^{\mathrm{c}, \mathrm{d}, \mathrm{e}}$ & $3,33^{\mathrm{e}, \mathrm{f}}$ & $14,27^{\mathrm{e}, \mathrm{f}}$ & $14,59^{\mathrm{e}, \mathrm{f}}$ & $18,48^{\mathrm{d}}$ \\
\hline 36 jam & $7,20^{\mathrm{f}, \mathrm{g}}$ & $6,94^{\mathrm{g}}$ & $7,62^{\mathrm{f}, \mathrm{g}}$ & $3,32^{\mathrm{e}, \mathrm{f}}$ & $1,98^{\mathrm{g}}$ & $1,16^{\mathrm{h}}$ & $19,51^{\mathrm{c}, \mathrm{d}}$ & $23,73^{\mathrm{b}}$ & $24,89^{\mathrm{a}, \mathrm{b}}$ \\
\hline $48 \mathrm{jam}$ & $8,17^{\mathrm{f}, \mathrm{g}}$ & $7,66^{\mathrm{f}, \mathrm{g}}$ & $8,88^{\mathrm{e}, \mathrm{f}}$ & $3,08^{\mathrm{f}}$ & $1,44^{\mathrm{g}, \mathrm{h}}$ & $1,05^{\mathrm{h}}$ & $21,44^{\mathrm{c}}$ & $24,78^{\mathrm{a}, \mathrm{b}}$ & $26,53^{\mathrm{a}}$ \\
\hline
\end{tabular}

Keterangan: Huruf di belakang angka yang berbeda menunjukkan berbeda nyata antar perlakuan $(p<0,05)$ 


\section{Kadar protein terlarut}

Tempe merupakan salah satu makanan hasil fermentasi yang populer di Indonesia yang terbuat dari kacangkacangan yang diinokulasikan dengan jamur Rhizopus oligosporus yang membentuk padatan kompak berwarna putih (Iswani 1996). Dibandingkan dengan bahan mentah yang digunakan yang umumnya berupa kedelai, tempe memiliki banyak keuntungan. Secara kimiawi, hal ini dapat dilihat dari kadar padatan terlarut, nitrogen terlarut, asam amino bebas, nilai cerna, nilai efisiensi protein, serta skor proteinnya.

Protein merupakan komponen utama dalam tempe karena tempe merupakan salah satu sumber protein nabati. Kara benguk merupakan salah satu anggota Leguminoceae yang pada umumnya merupakan sumber protein nabati, sehingga pada penelitian pembuatan tempe dengan variasi pengecilan ukuran dan lama fermentasi ini dilakukan pengukuran kadar protein terlarut (kadar asam amino bebasnya). Data kadar protein terlarut pada tempe kara benguk dengan variasi lama fermentasi dan pengecilan ukuran dapat dilihat pada Tabel 2 .

Berdasarkan Tabel 2, pada waktu fermentasi selama 0 jam, kadar protein terlarut pada tempe kara benguk biji utuh $(7,32 \mathrm{mg} / \mathrm{g})$ dan belah $(8,39 \mathrm{mg} / \mathrm{g})$ berbeda nyata dengan tempe kara benguk biji giling $(12,92 \mathrm{mg} / \mathrm{g})$, sedangkan antara tempe kara benguk biji utuh dan belah tidak berbeda nyata. Tempe kara benguk biji giling memiliki kadar protein terlarut yang lebih tinggi dibandingkan dua perlakuan ukuran biji yang lain. Hal ini disebabkan oleh proses pengukusan yang dilakukan sebelum fermentasi. Proses pengukusan dapat menyebabkan peningkatan kecernaan dan kelarutan protein. Semakin kecil ukuran biji kara benguk ditambah dengan proses pengukusan, semakin besar kadar protein terlarutnya.

Kadar protein pada fermentasi selama 12 jam berbeda nyata antara tempe kara benguk biji utuh dengan tempe kara benguk biji giling, sedangkan dengan tempe kara benguk biji belah tidak berbeda nyata. Kadar protein pada tempe kara benguk biji belah dan giling tidak berbeda nyata. Meskipun demikian, kadar protein pada tempe kara benguk biji giling lebih besar $(15,76 \mathrm{mg} / \mathrm{g})$ dibandingkan dengan dua ukuran yang lainnya $(12,85 \mathrm{mg} / \mathrm{g}$ dan 14,10 $\mathrm{mg} / \mathrm{g}$ ). Hasil tersebut menunjukkan bahwa kapang telah melakukan aktivitas metabolisme dan menghasilkan enzim proteinase, sehingga protein dipecah menjadi komponen yang lebih sederhana yaitu asam amino bebas (protein terlarut). Asam amino dihitung sebagai protein terlarut dengan pengujian metode Lowry karena adanya interaksi antara protein dan air, salah satunya terjadi melalui rantai cabang (gugus R) asam-asam amino (interaksi melalui ionisasi, polar, dan nonpolar) selain melalui ikatan peptida dalam rantai polipeptida (interaksi melalui dipol-dipol) (Marseno 1998).

Kadar protein pada fermentasi selama 24 jam berbeda nyata antara tempe kara benguk biji utuh dan belah dengan kara benguk biji giling, sedangkan antara tempe kara benguk biji utuh dan belah tidak berbeda nyata, dengan kadar protein pada biji utuh, belah, dan giling berturut-turut yaitu $14,27 \mathrm{mg} / \mathrm{g}, 14,59 \mathrm{mg} / \mathrm{g}$, dan $18,48 \mathrm{mg} / \mathrm{g}$. Kandungan protein pada tempe kara benguk biji belah dan giling lebih mudah didegradasi oleh kapang karena ukurannya yang lebih kecil dibandingkan dengan tempe kara benguk biji utuh, sehingga kadar protein terlarutnya lebih besar pada biji belah dan giling. Kadar protein pada fermentasi selama 24 jam ini mengalami kenaikan yang berbeda nyata daripada fermentasi sebelumnya pada tempe kara benguk biji giling (Tabel 2), namun tidak untuk dua macam ukuran biji yang lain. Hal ini diduga aktivitas kapang dalam mengurai protein lebih besar pada ukuran biji yang lebih kecil.

Fermentasi selama 36 jam dan 48 jam pada tempe kara benguk memberikan hasil kadar protein yang berbeda nyata antara kara benguk biji belah dan giling dengan kara benguk biji utuh. Berdasarkan Gambar 3 dan Tabel 2 yang menunjukkan kadar protein selama fermentasi, kadar protein juga mengalami peningkatan ketika fermentasi selama 36 jam dan 48 jam untuk semua varisi ukuran biji kara benguk.

Berdasarkan hasil penelitian diketahui bahwa lama fermentasi berpengaruh terhadap kadar protein tempe kara benguk. Selama proses fermentasi, terjadi degradasi komponen-komponen penyusun biji kara benguk, termasuk pemecahan protein menjadi komponen yang lebih sederhana. Semakin lama fermentasi maka jumlah protein yang terdegradasi menjadi asam amino semakin besar. Akan tetapi, apabila fermentasi ditambah waktunya maka akan dihasilkan amoniak yang memiliki flavour yang berbeda dan sampai akhirnya akan dihasilkan tempe kara benguk busuk. Asam amino lebih mudah larut dalam air dan nilai kecernaannya lebih tinggi. Perombakan menjadi asam amino berpengaruh terhadap flavour khas tempe yang dihasilkan. Proses metabolisme yang terjadi dalam tubuh manusia berlangsung dengan memecah protein menjadi komponen yang lebih sederhana, yaitu asam amino, karena asam amino ini yang akan digunakan oleh tubuh untuk metabolisme.

Asam amino yang berasal dari kara benguk termasuk asam amino eksogen karena disintesis di luar tubuh manusia dan disebut juga asam amino esensial, artinya didapatkan dari makanan sehari-hari (Winarno 2002). Menurut Wirahadikusumah (1989), terdapat sepuluh jenis asam amino esensial dan jenis asam amino yang paling banyak terdapat pada kacang-kacangan adalah asam amino lisin dan asam amino pembatasnya (asam amino dalam jumlah terbatas) adalah metionin (Muchtadi dan Sugiyono 1992). Menurut Salunkhe dan Kadam (1990), terdapat 17 jenis asam amino dalam kara benguk, 9 diantaranya adalah asam amino esensial, termasuk lisin yang menempati urutan ketiga terbesar.

Asam amino terhitung sebagai protein terlarut dengan metode pengujian Lowry. Hal ini disebabkan oleh adanya interaksi antara protein dan air, juga dapat berdasarkan sifat asam amino yang dapat larut dalam air, tidak larut dalam alkohol atau eter, dapat membentuk garam kompleks dengan logam berat (misalnya asam amino dengan $\mathrm{Cu}^{2+}$ membentuk senyawa kompleks berwarna biru tua), dan dapat membentuk senyawa berwarna biru dengan ninhidrin 
(Winarno 2002). Sifat mudah larut dalam air membuktikan bahwa asam amino memiliki sifat mengionik (ionik). Asam amino maupun protein dapat bereaksi dengan senyawa tertentu yang memberikan warna spesifik. Reaksi pewarnaan tersebut dapat digunakan untuk mendeteksi kadar asam amino atau protein secara kualitatif maupun kuantitatif. Sifat reaktif dari rantai samping (gugus R) asam amino terhadap senyawa tertentu merupakan salah satu reaksi yang akan memberikan warna spesifik. Misalnya gugus fenol pada tirosin dalam suasana alkali akan memberikan warna biru dengan phospo-molybdotungstate (folin-ciocalteau) (Marseno 1998).

Variasi pengecilan ukuran juga berpengaruh terhadap kadar protein telarut. Hal ini terlihat dalam setiap fermentasi. Setiap 12 jam pengujian kadar protein, terlihat pada perlakuan kara benguk giling memiliki kadar protein yang lebih tinggi apabila dibandingkan dengan dua perlakuan lainnya. Pada awal fermentasi (0 jam) sampai dengan akhir fermentasi, kadar protein terendah diperoleh pada tempe kara benguk biji utuh, pada tempe kara benguk belah lebih tinggi daripada tempe kara benguk biji utuh, dan tempe kara benguk giling memiliki kadar protein yang paling tinggi.

\section{Kadar asam fitat dan protein terlarut}

Kadar protein dalam biji kara benguk berkorelasi dengan kadar asam fitat. Dalam biji kara benguk mentah, sejumlah protein berikatan dengan asam fitat dalam biji kara benguk yang menyebabkan kelarutannya rendah setelah melalui tahap proses pembuatan tempe. Asam fitat efektif direduksi dengan proses fermentasi. Hal tersebut dibuktikan dari data yang diperoleh. Dengan korelasi yang berkebalikan dengan kadar asam fitat yang rendah maka kadar protein terlarut mengalami peningkatan karena kadar asam fitat yang berkurang, hal ini berarti protein yang berikatan dengan asam fitat semakin berkurang yang mengakibatkan kadar protein semakin meningkat selama fermentasi berlangsung. Korelasi antara kadar asam fitat dan kadar protein pada tempe kara benguk dengan variasi lama fermentasi dan pengecilan ukuran dapat dilihat pada Gambar 4.

Berdasarkan Gambar 4 terlihat bahwa kadar asam fitat pada ketiga jenis ukuran biji semakin mengalami penurunan dengan semakin lamanya waktu fermentasi. Terlihat juga tempe kara benguk biji utuh memiliki kadar asam fitat paling tinggi diantara kara benguk belah dan giling. Akan tetapi, kadar protein terlarut berkebalikan dengan grafik kadar asam fitat. Semakin lama fermentasi maka kadar protein terlarut semakin besar untuk semua jenis ukuran biji kara benguk. Terlihat juga tempe kara benguk biji utuh memiliki kadar protein terlarut paling kecil diantara kara benguk belah dan giling. Hal tersebut disebabkan miselium kapang lebih mudah menembus biji yang berukuran lebih kecil. Semakin mudah biji ditembus oleh miselium maka semakin mudah dan banyak enzim fitase yang dihasilkan oleh ragi dalam menghidrolisis asam fitat menjadi mioinositol dan ortoreduktase, dan semakin banyak pula protein yang diuraikan oleh kapang menjadi senyawa yang lebih sederhana yaitu asam amino bebas.
Masyarakat dalam mengonsumsi tempe kara benguk membutuhkan nutrien, termasuk protein, dalam jumlah yang optimal dan kandungan asam fitat yang seminimal mungkin. Berdasarkan hasil penelitian yang diperoleh (Tabel 2), tempe kara benguk dengan fermentasi selama 36 jam memiliki kandungan protein terlarut dalam jumlah paling besar dan kandungan asam fitat dengan jumlah paling rendah diantara lima variasi waktu fermentasi, dan tempe kara benguk biji giling dengan fermentasi selama 36 jam memiliki kadar protein terlarut tertinggi dan kadar asam fitat terendah diantara semua sampel. Secara penampilan, tempe kara benguk dengan fermentasi selama 36 jam dan 48 jam sudah kompak dan tidak berbeda nyata.

\section{KESIMPULAN}

Berdasarkan penelitian yang telah dilakukan, diketahui bahwa variasi lama fermentasi dan pengecilan ukuran berpengaruh pada kadar asam fitat. Semakin lama waktu fermentasi maka kadar asam fitat pada tempe kara benguk semakin rendah. Semakin kecil ukuran biji kara benguk yang akan diolah menjadi tempe maka kadar asam fitat semakin rendah. Variasi lama fermentasi dan pengecilan ukuran berpengaruh pada kadar protein terlarut. Semakin lama waktu fermentasi maka kadar protein terlarut semakin meningkat. Semakin kecil ukuran kara benguk yang akan diolah menjadi tempe maka kadar protein terlarutnya semakin rendah. Tempe kara benguk biji giling dengan fermentasi selama 36 jam mempunyai kadar asam fitat terendah $(1,16 \mathrm{mg} / \mathrm{g})$ dan kadar protein terlarut tertinggi $(24,89 \mathrm{mg} / \mathrm{g})$. Secara penampilan, tempe kara benguk dengan fermentasi selama 36 jam dan 48 jam sudah kompak dan tidak berbeda nyata. Tempe kara benguk pada fermentasi selama 36 jam mempunyai kadar asam fitat terendah dan kadar protein tertinggi di antara kelima variasi waktu karena dengan fermentasi selama 48 jam tidak berbeda nyata, sehingga merupakan waktu optimal fermentasi.

\section{DAFTAR PUSTAKA}

Apriadji H. 2008. Kedelai dan tempe masih dianggap sepele. www.docudesk.com. [29 Juli 2008].

Apriyantono A, Fardiaz D, Puspitasari NL et al. 1989. Petunjuk laboratorium analisis pangan. IPB Press, Bogor.

Arinanti M. 2005. Aktivitas Antioksidan Komponen Fenolik dan Asam Fitat pada Berbagai Jenis Kacang. [Tesis]. Universitas Gadjah Mada, Yogyakarta.

Buckle KA, Edwards RA, Fleet GH et al. 1985. Ilmu pangan. UI Press, Jakarta.

Davies NT, Nightingale R. 1975. The effect of pytate on intestinal absortion and secretion of zinc and manganese in rats. Br J Nutr 34 (2): 243-258.

Iswani L. 1996. Perbedaan Kebutuhan Energi Panas untuk Pengukusan Kedelai pada Berbagai Perlakuan Pencucian dalam Pembuatan Tempe. [Skripsi]. Universitas Gadjah Mada, Yogyakarta.

Marseno DW. 1998. Handout kimia hasil pertanian materi air, protein, dan enzim. UGM, Yogyakarta.

Muchtadi TR, Sugiyono. 1992. Ilmu pengetahuan bahan pangan. Dirjen Pendidikan dan Kebudayaan PAU Pangan dan Gizi, IPB, Bogor.

Pangastuti HP, Triwibowo P. 1996. Pengaruh lama fermentasi terhadap kandungan asam fitat dalam tempe kedelai. Cermin Kedokteran No 108, Jakarta. 
Pitojo S. 2003. Benih kedelai. Kanisius, Yogyakarta.

Reddy NR, Sathy SK, Salunki DK. 1982. Phytates in legumes and cereals. Adv Food Res 28: 1-92.

Rosningsih S. 2000. Pengaruh lama fermentasi dengan EM-4 terhadap kandungan ekskreta layer. Buletin Pertanian dan Peternakan 1 (2): 62 69.

Salunkhe DK, Kadam SS. 1990. Handbook world food legumes nutritional chemistry processing technology and utilization, Volume III. CRC Press, Florida.

Soedarmo P, Sediaoetama AD. 1977. Ilmu gizi. Dian Rakyat, Jakarta.

Sudarmadji S. 1975. Certain chemical and nutritional aspect of soybean tempe. Michigan State University, Michigan.

Sutardi. 1988. Phytase Activity During Tempe Production. [Thesis] Departement of Food Science and Technology, The university of New South Wales, New South Wales.
Tranggono S, Hastuti. 1993. Aktivitas fitase pada tahap-tahap pembuatan tempe kara benguk, kara putih, dan gude menggunakan inokulum Rhizopus oligosporus NRRL 2710. Agritech 13 (3): 1-5.

Wibowo D. 1990. Teknologi fermentasi. PAU Pangan dan Gizi, UGM, Yogyakarta.

Widowati S. 2008. Pemanfaatan hasil samping penggilingan padi dalam menunjang sistem agroindustri di pedesaan. Buletin Agrobio 4 (1): 33-38.

Winarno FG. 2002. Kimia pangan dan gizi. Gramedia Pustaka Utama, Jakarta.

Wirahadikusumah M. 1989. Biokimia protein, enzim, dan asam nukleat. ITB Press, Bandung. 